\title{
Pengembangan Modul Matematika dengan Pendekatan Science, Technology, Engineering, And Mathematics (STEM) pada Materi Segiempat
}

\author{
Taza Nur Utami ${ }^{1}$, Agus Jatmiko ${ }^{1}$, Suherman ${ }^{1}$ \\ ${ }^{1}$ Universitas Islam Negeri Raden Intan Lampung. Jalan Endro Suratmin, Sukarame, Bandar \\ Lampung 35133, Indonesia. \\ *Corresponding Author. E-mail: tazautami@gmail.com
}

Received : 19-03-2018; Revised : 13-05-2018; Accepted : 30-05-2018

\begin{abstract}
Abstrak
Penelitian ini bertujuan untuk mengetahui kelayakan modul matematika dengan pendekatan STEM serta respon peserta didik dan guru terhadap kemenarikan modul. Prosedur penelitian dan pengembangan yang digunakan adalah model pengembangan Borg dan Gall yang dimodifikasi oleh sugiyono. Instrumen pengumpulan data yang digunakan adalah angket yang diberikan kepada para ahli untuk mengetahui kelayakan produk dan angket yang diberikan kepada peserta didik dan guru untuk mengetahui kemenarikan produk. Hasil penelitian menunjukkan bahwa penilaian dari para ahli sangat layak (87\% ahli materi, $89 \%$ ahli media dan $92 \%$ ahli bahasa), respon peserta didik dan guru sangat menarik (89\% uji coba kelompok kecil, $87 \%$ uji coba lapangan dan $90 \%$ uji coba guru).

Kata kunci: Pengembangan; Modul; Science, Technology, Engineering, and Mathematics (STEM); Segiempat
\end{abstract}

\begin{abstract}
This study aims to determine the feasibility of mathematical modules with STEM approach and the response of learners and teachers to the attractiveness of the module. The research and development procedure used is the Borg and Gall development model modified by sugiyono. The data collection instruments used are questionnaires given to experts to know the feasibility of the products and questionnaires given to learners and teachers to know the attractiveness of the product. The results of the study indicate that the assessment of the experts is very reasonable (87\% of material experts, 89\% of media experts and $92 \%$ of linguists), the response of learners and teachers is very interesting (89\% small group trial, $87 \%$ field trials and $90 \%$ teacher test).
\end{abstract}

Keywords: Development; Module; Science, Technology, Engineering, and Mathematics (STEM); Quadrilateral

\section{PENDAHULUAN}

Aspek terpenting pada pengembangan suatu Negara adalah pendidikan. Hadirnya kurikulum 2013 merupakan upaya yang telah dilakukan pemerintah untuk mengembangkan pendidikan di Indonesia, mengingat persaingan di abad 21 yang menuntut sumber daya manusia yang kompeten dalam sains, teknologi, desain teknik dan matematika sehingga diharapkan pendidikan dapat mengintegrasikan empat disiplin ilmu (Milaturrahmah, Mardiyana, \& Pramudya, 2017).
Matematika menduduki peran penting dalam dunia pendidikan karena menjadi dasar dan perkembangan ilmu yang lain (Putra \& Anggraini, 2016; Yusnita, Masykur, \& Suherman, 2016). Namun, pembelajaran matematika masih dianggap sulit oleh sebagian peserta didik (Fadholi, Waluya, \& Mulyono, 2015; Fitri, Helma, \& Syarifuddin, 2014; Fitriasari, 2017). Pada umumnya dalam mempelajari pelajaran yang dianggap sulit, peserta didik cenderung menunjukkan minat belajar dan motivasi berprestasi yang rendah pula (Suherman, 2015). Mengingat pentingnya 
matematika, maka sangat diharapkan peran seorang guru agar dapat menentukan pendekatan pembelajaran yang dapat merubah pola fikir dan pandangan peserta didik terhadap matematika, (Saparwadi, 2016).

Salah satu pendekatan pembelajaran yang sesuai dengan kurikulum 2013 adalah pendekatan STEM (Gustiani, Widodo, \& Suwarma, 2017). Pendekatan STEM merupakan pendekatan pembelajaran yang menggabungkan dua atau lebih bidang ilmu yang termuat dalam STEM yaitu sains, teknologi, teknik/rekayasa, dan matematika. (Ismayani, 2016). Melalui pendekatan STEM diharapkan peserta didik memiliki keterampilan belajar dan berinovasi yang meliputi berpikir kritis, kreatif, inovatif, serta mampu berkomunikasi dan berkolaborasi (Winarni, Zubaidah, \& Koes, 2016).

Keberhasilan suatu pembelajaran, selain tergantung pada metode yang digunakan juga sangat tergantung pada perangkat pembelajaran yang digunakan. Buku sebagai bahan ajar dan sumber belajar dipandang sebagai faktor penting dalam menentukan kesuksesan pelaksanaan kurikulum 2013 (Tjiptiany, As'ari, \& Muksar, 2016), Seiring dengan berjalannya kurikulum 2013, pemerintah menerbitkan buku paket kurikulum 2013 yang digunakan untuk peserta didik dan guru disekolah, termasuk buku matematika. Studi pendahuluan yang dilakukan oleh (Tjiptiany, As'ari, \& Muksar, 2016) memperoleh kesimpulan bahwa membelajarkan peserta didik dengan menggunakan buku paket belum memberikan hasil yang optimal. Selain itu, berdasarkan hasil wawancara dan observasi di SMP Negeri 3 Jati Agung, SMP Negeri 24 Bandar Lampung, dan MTs Negeri 2 Bandar Lampung, didapat permasalahan yang sama yaitu peserta didik masih mengalami kesulitan dalam memahami materi di buku paket dan belum adanya modul yang dikembangkan oleh guru untuk menunjang proses pembelajaran di dalam kelas. Berdasarkan alasan itulah maka mendorong peneliti untuk mengembangkan bahan ajar yang dapat mempermudah peserta didik dalam memahami materi dan sesuai dengan harapan kurikulum 2013.

Bahan ajar yang dikembangkan peneliti dalam penelitian ini yaitu berupa modul. Modul merupakan sebuah bahan ajar yang bertujuan membuat peserta didik belajar secara mandiri tanpa atau dengan bimbingan pendidik, sehingga modul paling tidak berisi tentang komponen pokok bahan ajar (Diana, Netriwati, \& Suri, 2018; Sari, Farida, \& Syazali, 2016). Menurut Pratiwi modul adalah salah satu bentuk bahan ajar yang dikemas secara lengkap dan sistematis yang memuat seperangkat pengalaman belajar yang terencana dan didesain untuk membantu peserta didik menguasai tujuan pembelajaran (Pratiwi, Hidayah, \& Martiana, 2017).

Sebuah penelitian menunjukkan bahwa modul efektif digunakan dalam pembelajaran, karena lebih dari 60\% siswa tuntas belajar. Modul efisien digunakan sebagai bahan ajar dalam pembelajaran karena menggunakan waktu lebih sedikit dan modul menarik siswa sebagai bahan ajar (Astiti, 2014). Penelitian yang dilakukan oleh (Becker \& Park, 2011) menunjukan bahwa pendekatan STEM memiliki efek positif pada pembelajaran peserta didik. Pendekatan STEM dalam pembelajaran mampu melatih peserta didik baik secara kognitif, keterampilan, maupun afektif, selain itu peserta didik tidak hanya diajarkan secara teori saja, tetapi juga praktik sehingga peserta didik mengalami langsung proses pembelajaran (Septiani,2016).

Pengembangan modul dirasa sangat efektif untuk mengatasi kesulitan siswa dalam belajar karena modul disusun dengan konsep yang menarik 
dan menggunakan karakteristik pendekatan STEM, dengan mencantumkan lab-mini, kegiatan proyek, jelajah IT, serta dilengkapi dengan ilustrasi-ilustrasi berupa gambar yang dapat mempermudah peserta didik dalam memahami materi.

\section{METODE}

Metode yang digunakan dalam penelitian dan pengembangan ini mengacu pada model pengembangan Borg dan Gall yang dimodifikasi dari Sugiyono dan terdiri dari sepuluh langkah. Semua prosedur penelitian tentu saja bukan merupakan langkahlangkah baku yang harus diikuti sepenuhnya secara keseluruhan. Setiap pengembang tentu saja dapat memilih dan menentukan langkah-langkah yang paling tepat bagi dirinya berdasarkan kondisi khusus yang dihadapinya dalam proses pengembangan (Haryanto et al., 2015).

Penelitian ini melibatkan subyek penelitian untuk uji coba kelompok kecil sebanyak 12 orang, untuk uji coba lapangan sebanyak 70 orang, dan untuk uji coba guru sebanyak 3 guru matematika. Instrumen penelitan menggunakan lembar validasi ahli, angket respon peserta didik dan angket respon guru. Teknik analisis data yang digunakan adalah teknik analisis deskriptif kuantitatif, yaitu memaparkan hasil pengembangan produk berupa modul matematika dengan pendekatan STEM pada materi segiempat dan . Data yang diperoleh melalui angket dari para ahli, peserta didik dan guru yang berupa data kuantitatif diubah menjadi data kualitatif. Dari hasil analisis data akan diperoleh kesimpulan tentang kelayakan modul menggunakan Skala Likert dengan kriteria seperti pada Tabel 1 berikut:

Tabel 1. Kriteria Interpretasi Kelayakan

\begin{tabular}{cc} 
Penilaian & $\begin{array}{c}\text { Kriteria } \\
\text { Interpretasi }\end{array}$ \\
$81 \% \leq P \leq 100 \%$ & Sangat layak \\
$61 \% \leq P<81 \%$ & Layak \\
$41 \% \leq P<61 \%$ & Cukup layak \\
$21 \% \leq P<41 \%$ & Tidak layak \\
$0 \% \leq P<21 \%$ & Sangat tidak layak \\
\hline
\end{tabular}

(Novianti, 2015)

Adapun prosedur yang dilakukan dalam penelitian ini ditunjukkan pada Gambar 1. 


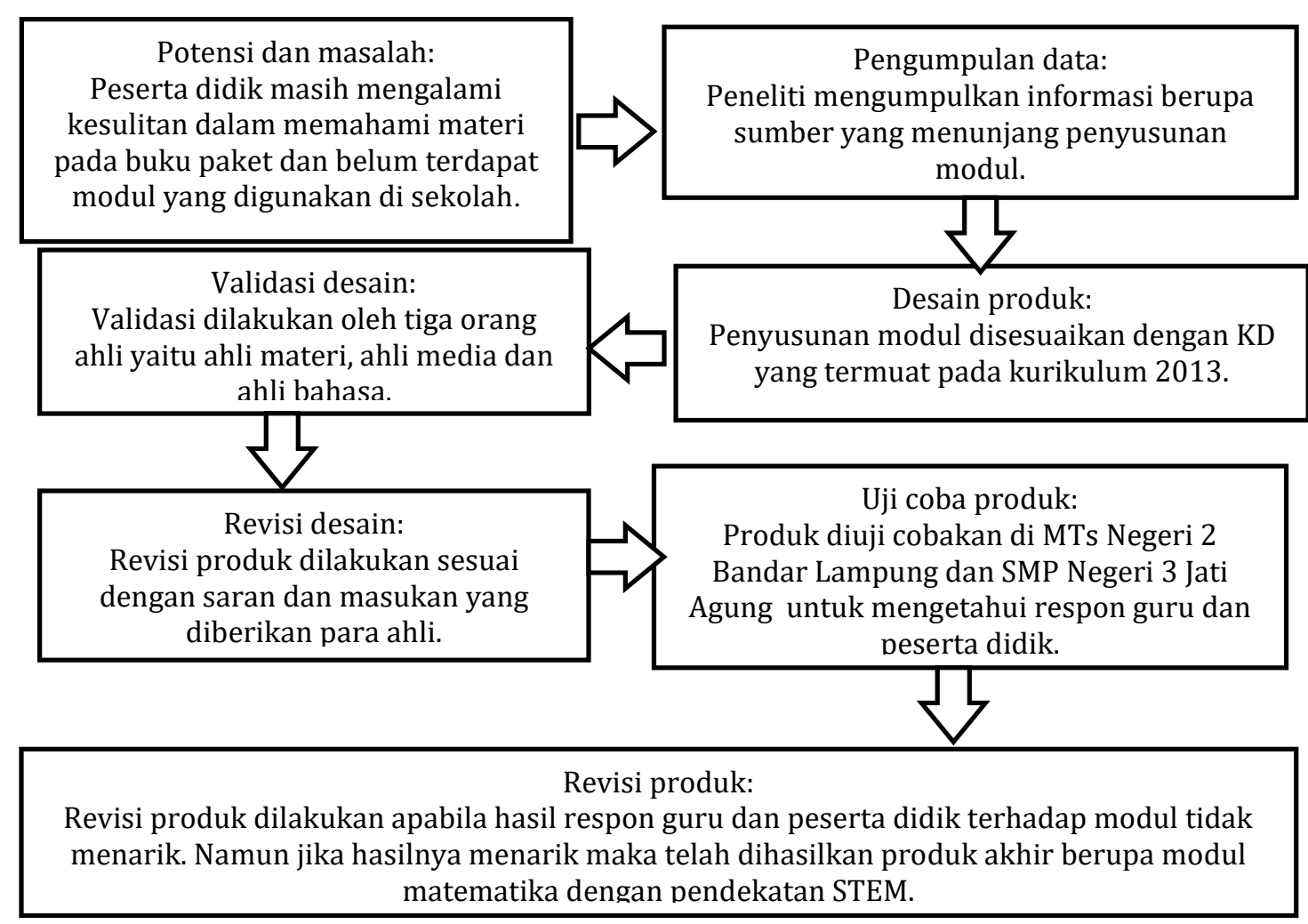

\section{Gambar 1. Prosedur penelitian yang dilakukan}

\section{HASIL DAN PEMBAHASAN}

\section{Hasil}

Penelitian dan pengembangan ini dilaksanakan di MTsN 2 Bandar Lampung dan SMPN 3 Jati Agung untuk mengetahui kemenarikan modul segiempat dengan pendekatan STEM. Berdasarkan prosedur penelitian pengembangan modul matematika dengan pendekatan STEM yang telah dilakukan, diperoleh hasil sebagai berikut.

\section{Potensi dan Masalah}

Identifikasi masalah pada penelitian ini diperoleh dari hasil wawancara dan observasi yang dilakukan di beberapa SMP/MTs diantaranya di SMP Negeri 3 Jati Agung, SMP Negeri 24 Bandar Lampung dan MTsN 2 Bandar Lampung. Berdasarkan hasil wawancara dan observasi yang peneliti lakukan di ketiga sekolah tersebut, terdapat permasalahan yang sama pada peserta didik yaitu peserta didik masih mengalami kesulitan dalam memahami materi pada buku paket dan belum adanya modul yang dikembangkan oleh guru.

\section{Pengumpulan Data}

Setelah proses potensi dan masalah selesai, maka tahap selanjutnya yaitu mengumpulkan informasi berupa sumber yang menunjang penyusunan modul. Pengkajian bahan materi dalam modul dilakukan dengan pengumpulan sumber dan referensi serta gambargambar yang berhubungan dengan materi segiempat.

\section{Desain Produk}

Penyusunan modul matematika dengan pendekatan STEM pada materi segiempat disesuaikan dengan kompetensi dasar yang termuat pada kurikulum 2013. Modul ini menggunakan ukuran kertas B5; skala space 1,5; font 10 pt; jenis huruf Comic Sans MS dan Kristen ITC. Program utama dalam pembuatan modul ini menggunakan Microsoft Word 
2007. Selain itu juga menggunakan program pendukung yaitu CorelDraw X7 dan Adobe Photoshop. Modul ini terdiri dari bagian awal, bagian isi modul dan bagian penutup.

\section{Validasi Desain}

Validasi desain diuji oleh 7 ahli yang terdiri dari 3 ahli materi, 2 ahli media, dan 2 ahli bahasa. Ahli materi memberikan penilaian pada komponen kelayakn isi, kelayakan penyajian, dan kelayakan pendekatan STEM. Ahli media memberikan penilaian terhadap komponen kelayakan kegrafikan, sedangkan ahli bahasa memberikan penilaian pada komponen kelayakan bahasa. Adapun hasil rekapitulasi validasi oleh para ahli pada tahap 1 dan tahap 2 dapat dilihat pada diagram berikut.

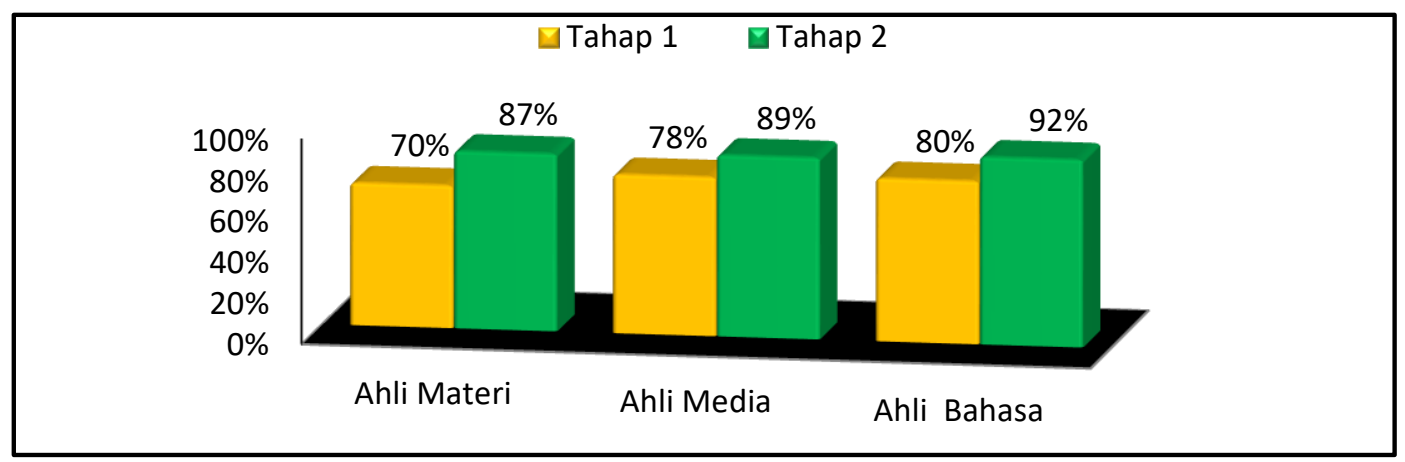

\section{Gambar 3. Diagram rekapitulasi hasil validasi oleh para ahli}

Berdasarkan grafik pada gambar 3, terjadi peningkatan hasil validasi dari tahap 1 ke tahap 2. Dengan demikian, masukan dan saran dari para ahli memberikan pengaruh terhadap pengembangan produk.

\section{Revisi Desain}

Setelah dilakukan validasi produk tahap 1 oleh para ahli materi, ahli media dan ahli bahasa, terdapat banyak masukan dan saran yang diberikan oleh para ahli terhadap produk yang dikembangkan. Sehingga dilakukan revisi produk sesuai masukan dan saran dari para ahli agar produk yang dikembangkan menjadi produk yang sangat layak dan siap untuk diuji cobakan.

\section{Uji Coba Produk}

Setelah produk direvisi sesuai saran dan masukan dari para ahli, maka produk dapat diuji cobakan ke peserta didik dan guru. Uji coba dilakukan untuk mengetahui respon peserta didik dan guru terhadap kemenarikan produk yang telah dibuat. Uji coba ini dilakukan di SMPN 3 Jati Agung dan MtsN 2 Bandar Lampung. Uji coba produk dilakukan dengan uji coba kelompok kecil yang terdiri dari 12 peserta didik, uji coba lapangan yang terdiri dari 70 peserta didik dan uji coba guru yang terdiri dari 3 guru matematika. Adapun hasil uji coba produk dapat dilihat pada Gambar 4. 
Desimal, 1 (2), 2018 - 170

Taza Nur Utami, Agus Jatmiko, Suherman

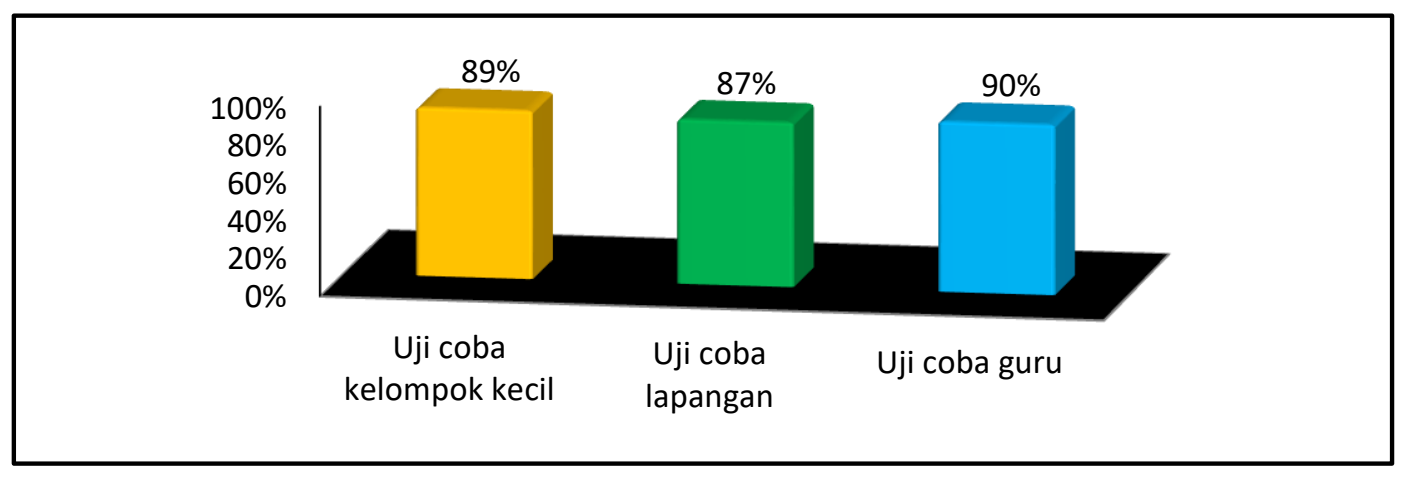

Gambar 4. Diagram hasil uji coba

\section{Revisi Produk}

Setelah dilakukan uji coba kelompok kecil, uji coba lapangan dan uji coba guru, diketahui bahwa modul matematika segiempat dengan pendekatan STEM memperoleh kriteria interpretasi "Sangat Menarik", maka dapat dikatakan bahwa modul ini telah selesai dikembangkan sehingga menghasilkan produk akhir.

\section{Pembahasan}

Penelitian ini menghasilkan produk berupa modul matematika dengan pendekatan STEM pada materi segiempat. Modul ini disusun berdasarkan kompetensi dasar yang termuat pada kurikulum 2013. Modul ini dilengkapi dengan kegiatan yang merupakan karakteristik dari pendekatan STEM, seperti yang terdapat pada lab-mini matematika dan kegiatan proyek.

$$
\text { Model penelitian dan }
$$
pengembangan ini mengacu pada model pengembangan Borg and Gall yang dimodifikasi dari Sugiyono yang terdiri dari sepuluh langkah. Semua prosedur penelitian tentu saja bukan merupakan langkah-langkah baku yang harus diikuti sepenuhnya secara keseluruhan. Menurut Ardana setiap pengembangan tentu saja dapat memilih dan menentukan langkah-langkah yang paling tepat bagi dirinya berdasarkan kondisi khusus yang dihadapinya dalam proses pengembangan. Oleh karena itu, penelitian ini hanya dilakukan sampai langkah ke 7.
Produk yang telah jadi kemudian divalidasi oleh para ahli yaitu ahli materi, ahli media, dan ahli bahasa. Hasil penilaian para ahli materi menunjukan kriteria "Sangat Layak" yaitu dengan presentase rata-rata $89 \%$. Hasil penilaian para ahli media menunjukan kriteria "Sangat Layak" yaitu dengan persentase rata-rata 90\%. Selanjutnya validasi juga dilakukan oleh ahli bahasa yang menunjukan kriteria "Sangat Layak" yaitu dengan persentase rata-rata 92\%.

Setelah tahap validasi selesai, produk diuji cobakan melalui tiga tahap yaitu uji kelompok kecil, uji lapangan dan uji coba guru. Hasil uji coba kelompok kecil menunjukan bahwa modul sangat menarik dengan skor presentase ratarata 88\%. Begitu juga pada uji coba lapangan, modul yang peneliti kembangkan mendapatkan respon sangat menarik dengan skor presentase rata-rata $89 \%$. Untuk uji coba guru skor presentase rata-rata yang diperoleh lebih tinggi dari uji coba kelompok kecil dan uji coba lapangan yakni $92 \%$ dengan kriteria yang sama yaitu sangat menarik.

Dengan demikian modul matematika dengan pendekatan STEM pada materi segiempat ini layak untuk digunakan dalam kegiatan pembelajaran matematika. Oleh karena itu diharapkan dengan adanya modul ini dapat membantu peserta didik dalam menjalankan sebuah proses untuk menemukan suatu konsep pemahaman matematika dengan mudah dan membantu peserta didik untuk lebih 
mengembangkan ilmu yang dimiliki pada kehidupan nyata. Adapun kelebihan dan kekurangan modul matematika dengan pendekatan STEM pada materi segiempat adalah sebagai berikut.

Kelebihan modul matematika dengan pendekatan STEM pada materi segiempat yang dikembangkan antara lain: (1) sebagai penuntun belajar bagi peserta didik secara mandiri; (2) modul yang disusun dengan pendekatan STEM, dilengkapi dengan lab-mini matematika yang dapat mempermudah peserta didik untuk menemukan sebuah konsep pada materi segiempat dan sehingga peserta didik mengetahui bagaimana konsep itu didapat, selain itu terdapat kegiatan proyek yang dapat menambah pengetahuan peserta didik untuk menerapkan pengetahuan yang dimiliki dalam kehidupan nyata; (3) modul ini memiliki banyak ilustrasi yang dapat mempermudah peserta didik dalam memahami materi.

Kekurangan pada pengembangan ini adalah materi yang terdapat dalam modul menggunkan pendekatan STEM masih sebatas materi segiempat saja sehingga perlu dikembangkan lebih luas lagi.

\section{SIMPULAN DAN SARAN}

Hasil validasi ahli materi terhadap modul matematika dengan pendekatan STEM pada materi segiempat memperoleh skor rata-rata persentase sebesar 87\% dengan kriteria "sangat layak", selain itu hasil validasi ahli media memperoleh skor persentase sebesar 89\% dengan kriteria "sangat layak", dan hasil validasi ahli bahasa mendapatkan skor 92\% dengan kriteria "sangat layak". Respon peserta didik terhadap modul matematika dengan pendekatan STEM pada materi segiempat diperoleh skor rata-rata persentase sebesar $88 \%$ ( $89 \%$ uji coba kelompok kecil dan $87 \%$ uji coba lapangan) dengan kriteria "sangat menarik", dan respon guru diperoleh skor rata-rata persentase sebesar $90 \%$ dengan kriteria "sangat menarik".

Modul hanya menyajikan materi segiempat saja sehingga diharapkan dapat dilakukan pengembangan pada materi yang lain. Kegiatan proyek pada modul sebaiknya selalu diperbarui mengikuti perkembangan zaman agar peserta didik dapat mengetahui lebih banyak manfaat ilmu matematika dalam kehidupan nyata.

\section{DAFTAR PUSTAKA}

Becker, K., \& Park, K. (2011). Effects of integrative approaches among science, technology, engineering , and mathematics ( STEM ) subjects on students ' learning : A preliminary meta-analysis. Journal of STEM Education, 12(5), 23-37.

Diana, M., Netriwati, \& Suri, F. I. (2018). Modul pembelajaran matematika bernuansa Islami dengan pendekatan inkuiri. Desimal, 1(1), $7-$ 13.

Fadholi, T., Waluya, B., \& Mulyono. (2015). Analisis pembelajaran Matematika dan kemampuan literasi serta karakter siswa SMK. Unnes Journal of Mathematics Education Research, 4(1), 42-48.

Fitri, R., Helma, \& Syarifuddin, H. (2014). Penerapan Strategi The Firing Line pada Pembalajaran Matematika Siswa Kelas XI IPS SMA Negeri 1 Batipuluh. Jurnal Pendidikan Matematika, 3(1), 18-22.

Fitriasari, P. (2017). Pemanfaatan Software Geogebra Dalam Pembelajaran Matematika. Jurnal Pendidikan Matematika RAFA, 3(1), 57-69.

Gustiani, I., Widodo, A., \& Suwarma, I. R. (2017). Development and validation of science, technology, engineering and mathematics (STEM) based instructional material. In $A I P$ Conference Proceedings (pp. 1-7). 
Haryanto, Try Sevita, Dwiyogo, Wasis Djoko, Sulistyorini. (2015). Pengembangan Pembelajaran Permainan Bolavoli Menggunakan Media Interaktif Di SMP Negeri 6 Kabupaten Situbondo. Pendidikan Jasmani , 25 (1), 123-128.

Ismayani, A. (2016). Pengaruh penerapan STEM project- based learning terhadap kreativitas matematis siswa SMK. Indonesian Digital Journal of Mathematics and Education, 3(4), 264-272.

Milaturrahmah, N., Mardiyana, M., \& Pramudya, I. (2017). Mathematics Learning Process with Science, Technology , Engineering , Mathematics ( STEM ) Approach in Indonesia. In International Conference on Mathematics and Science Education (ICMScE) (pp. 17).

Novianti, D. A. (2015). Pengembangan Modul Akuntansi Aset Tetap Berbasis Pendekatan Saintifik Sebagai Pendukung Implementasi K13 di SMKN 2 Buduran. Jurnal Pendidikan, 3 (1), 1-9.

Pratiwi, P. H., Hidayah, N., \& Martiana, A. (2017). Pengembangan modul mata kuliah penilaian pembelajaran sosiologi berorientasi HOTS. Cakrawala Pendidikan, 36(2), 201208.

Putra, R. W. Y., \& Anggraini, R. (2016). Pengembangan Bahan Ajar Materi Trigonometri Berbantuan Software iMindMap pada Siswa SMA. Jurnal Pendidikan Matematika, 7(1), 39-47.

Sari, F. K., Farida, \& Syazali, M. (2016). Pengembangan media pembelajaran (modul) berbantuan geogebra pokok bahasan turunan. Al-Jabar: Jurnal Pendidikan Matematika, 7(2), 135-151.

Saparwadi, L. (2016). Efektivitas Metode Pembelajaran Drill dengan Pendekatan Peer Teaching Ditinjau dari Minat dan Prestasi Belajar
Matematika Siswa. Jurnal Didaktik Matematika, 3(1), 39-46.

Septiani, A. (2016). Penerapan Asesmen Kinerja Dalam Pendekatan STEM (Sains teknologi engiineering matematika) untuk Mengungkap keterampilan Proses Sains. Isu-Isu Kontemporer Sains, Lingkungan, dan Inovasi Pembelajarannya (pp. 654659). Surakarta: Universitas Muhammadiyah Surakarta.

Suherman. (2015). Kreativitas Siswa Dalam Memecahkan Masalah Matematika Materi Pola Bilangan dengan Pendekatan Matematika Realistik (PMR). Al-Jabar: Jurnal Pendidikan Matematika, 6(1), 81-90.

Tjiptiany, E. N., As'ari, A. R., \& Muksar, M. (2016). Pengembangan Modul Pembelajaran Untuk Membantu Siswa Sma Kelas X Dalam Memahami Materi Peluang. Jurnal Pendidikan, 1(10), 1938-1942.

Winarni, J., Zubaidah, S., \& Koes, S. (2016). STEM: Apa, Mengapa, Dan Bagaimana. Prosiding Semnas Pend IPA Pascasarjana UM.

Yusnita, I., Masykur, R., \& Suherman. (2016). Modifikasi Model Pembelajaran Gerlach dan Ely Melalui Integrasi Nilai-Nilai Keislaman Sebagai Upaya Meningkatkan Kemampuan Representasi Matematis. Al-Jabar: Jurnal Pendidikan Matematika, 7(1), 29-38. 